\title{
Las Inhibition of Diffusion and Uptake of Tritiated Uridine During Teleost Embryogenesis
}

\author{
Carol Muehleman \\ Loyola University Chicago
}

Follow this and additional works at: https://ecommons.luc.edu/luc_theses

Part of the Biology Commons

\section{Recommended Citation}

Muehleman, Carol, "Las Inhibition of Diffusion and Uptake of Tritiated Uridine During Teleost Embryogenesis" (1976). Master's Theses. 2832.

https://ecommons.luc.edu/luc_theses/2832

This Thesis is brought to you for free and open access by the Theses and Dissertations at Loyola eCommons. It has been accepted for inclusion in Master's Theses by an authorized administrator of Loyola eCommons. For more information, please contact ecommons@luc.edu. c) (i) (9)

This work is licensed under a Creative Commons Attribution-Noncommercial-No Derivative Works 3.0 License. Copyright (c) 1976 Carol Muehleman 
LAS INAIBITION OF DIFTUSION AND UPTAKE OF TRITIATED URIDINE DURING TELEOST EMBRYOGEITESIS

by

Carol Muehleman

A Thesis Submitted to the Faculty of the Graduate SchooI of Loyola University of Chicago in Partial Fulfillment of the Requirements for the Degree of Master of Science

February

1976 
ACKNOWLEDGMENTS

I am deeply grateful to Dr. Harold W. Manner for his ever-present guidance and inspiration throughout the course of my graduate studies and thesis preparation.

Credit for the preparation of a portion of the photographic work in this thesis goes to Mark Vancura.

A special word of gratitude is extended to Ken for providing me with the proper attitude necessary for furthering my education. 
VITA

Date and Place of Birth: April 24, 1952; Chicago, Ill.

Schools and Universities Attended: St. Viator Grade School, Madonna High School, DePaul University - B.S. in Biology conferred in June, 1974, Loyola University M.S. in Biology conferred in February, 1976.

Pertinent Under oraduate Course Work: Botany, Cell Biology, Erbryology, Environmental Biology, Genetics, Immunology, Mammalian Anatorny, Mammalian Physiology, Microbiology, General Chemistry, Oualitative Analysis, Quantitative Analysis, Bio-organic Chemistry I, II, and III, Environmental Chemistry, College Physics I, II, and III, Physics of the Human Body.

Pertinent Graduate Course Work: Experinental Morphogenesis, General Physiology, Iimnology, Parasitology, Plant Growth and Development, Graduate Research I, II, and III.

Memberships in Honor Societies: Alpha Lambda Delta Honor Society and Beta Beta Beta Honor Society.

Published Works:

Wuehleman, C. (with H. Manner) 1975. Changes in the permeability of the teleost chorion during embryogenesis. Trans. Viid. Dev. Biol. Conf. 1975: 21 .

Muehleman, C. (with H. Manner) 1975. Permeability and uptake of tritiated uridine during teleost embryogenesis. Sci. Biol. Jour. 1: 81-82. 
Acknowledgements . . . . . . . . . . . . Page Vita . . . . . . . . . . . . . . . iii List of Tables . . . . . . . . . . . . . . . List of Figures . . . . . . . . . . . . . . . vi Introduction . . . . . . . . . . . . . . . I Review of the Literature . . . . . . . . 4 Materials and Methods . . . . . . . . . 19 Results . . . . . . . . . . . . 24 Discussion . . . . . . . . . . . 46 Literature Cited . . . . . . . . . . 49 


\section{LIST OF TABLES}

Table

Page

1. Scintillation counts of control embryos . . . . . . . . . . . . 27

2. Scintillation counts of IAS-treated embryos . . . . . . . . . . . . 31

3. Number of pore-like structures on chorions of control embryos . . . . . . . 41

4. Number of pore-like structures on chorions of LAS-treated embryos . . . . . . 43 
Figure

Page

1. Chorions observed with an optical

micrometer on a compound microscope . . . . 23

2. Power curve of the scintillation counts of control eribryos . . . . . . . 29

3. Power curves of the scintillation counts of control and IAS-treated embryos . . 33

4. Chorion of a fathead minnow embryo of 5 hours post-fertilization ........ 35

5. Chorion of a fathead minnow embryo of 33 hours post-fertilization . . . . . . 35

6. Chorion of a fathead minnow embryo of 48 hours post-fertilization ... . . . . . 37

7. Chorion of a fathead minnow embryo of 72 hours post-fertilization .. . . . . 37

8. Chorion of a fathead minnow embryo of 96 hours post-fertilization . . . . . . 39

9. Bar-graph of the mean number of porelike structures on chorions of control and IAS-treated erbryos. . . . . . . . 45 


\section{IITRODUCTIONT}

The djfferential response of embryos at dissimilar stages of embryogenesis to comparable dosages of aquatic pollutants has been explained as a differential susceptibility of embryonic tissues to these pollutants (Manner and Thompson, 1974). Although this is undoubtedly true, it is also possible that the vitelline membrane or the chorion, acting as barriers between the embryo and its aquatic environment, may allow different amounts of pollutants to pass into the embryo at specific stages of embryogenesis. Thus, the differential response to pollutants may be due to differing amounts of these pollutants entering the embryo. It is for this reason that an analysis of tritiated uridine diffusjon into the fathead minnow (Pimenhales promelas Rafinesque) embryo was studied. Any change in the amount of tritiated uridine entering and remaining within the confines of the chorion may reflect a change in the diffusion through the vitelline memorane or the chorion. However, this change could also reflect changing cellular netabolic needs during embryogenesis. Therefore, in this study, I will refer to any change in the amount of tritiated uridine entering and remaining within the embrvo as a change in the diffusion and uptake of tritiated uridine.

A pollutant which is currently under investigation in many laboratories is linear alkry benzene sulfonate (IAS), 
a component of biodegradable detergents. The current interest in IAAS in the Chicago area arose because it is found in low concentrations in the waters of this area (Vaughn et a], 1973).

IAS is the most commonly used surfactant in the detergents presently used in the United States. It is similar to the surfactants used ten years ago except that LAS is biodegradable, i.e., readily broken down by the action of bacteria present in the environment.

LAS, at various concentrations, has been found to be both teratogenic and toxic to some teleost embryos. Brain and eye abnormalities in teleosts have been found to be caused by LAS present in the water (Manner and Dewese, 1973). JAS is a surface acting agent (Stoker and seager, 1972). This property suggests that it might alter the structures of the vitelline membrane or chorion, thereby changing their respective diffusion properties. It is the purpose of this thesis to determine whether or not LAS has an effect on the diffusion and uptake of tritiated uridine in the fathead ninnow embryo.

The conventional fish used in detergent studies have been the zebra fish (Brachydanio rerio), the Japnese Medaka (Oryzias latipes), the killifish (Fundulus heteroclites), and the fathead minnow (Pimephales promelas). The fathead minnow is indigenous to the United States and it is used qui.te extensively by the Environmental Protection Agency. It is for these reasons that the fathead minnow was used 
in this particular study.

The fathead minnow embryo was used in this study and it is surrounded by a vitelline or fertilization membrane and a chorion throughout its period of embryogenesis. It is through the outermost membrane, the chorion, that aquatic pollutants must pass in order to reach the embryo to produce their teratogenic and toxic effects. Also, if there is a change in diffusion and uptake of tritiated uridine over developmental time, it could possibly be due to a change in chorionic structure during enbryogenesis. Therefore, for this thesis, an investigation was also made into the surface structure of the chorion through the period of fathead minnow embryogenesis, both with and without I,AS treatment. 


\section{REVIEW OF THE LITERATURE}

Diffusion and Uptake

Biological membranes act as incomplete barriers between two separate compartments. They are incomplete in that a transfer of molecules across them and between the compartments they are separating may still occur. This transfer has been postulated to be of two main types, diffusion and carrier transport (Neame et al., 1972).

Diffusion is characterized by the net flow of molecules from a region of higher concentration to a region of lower concentration. This net flow is both spontaneous and random and is in keeping with the second law of thermodynamics which states that energy will spontaneously pass from a region of higher energy to a region of lower energy. Therefore, the amount of free energy available decreases.

Diffusion can be exemplified by the addition of solute to solvent. The molecules will distribute themselves until there exists a homogeneous mixture of solute and solvent. This diffusion process, also called passive or simple diffusion, maintains a rate which is directly proportional to the solute concentration and which is directed merely by physical forces. Passive diffusion is an exergonic process and other factors affecting its rate include the molecular weights of the interacting molecules, the distance the 
molecules must travel and the temperature of the entire molecular system itself (Dowben, 1971; Guyton, 1971).

Diffusion through membrane barriers is a common entity in all living systems, however, diffusion alone can not explain all molecular transfer across these barriers. Therefore, a second type of transfer mechanism, carrier transport, has been postulated. The movement of molecules through a membrane barrier at a rate which is greater than possible by diffusion alone and which displays enzyme kinetic properties is called carrier transport.

The general carrier transport mechanism entails the attachment of solute molecules to carrier sites thereby forming complexes which move across the membrane. The solute molecules may then be released on the other side of the membrane. If the solute concentration is great enough to cause all of the carrier sites in the membrane to be occupied then saturation will occur; in which case the rate of transfer is at a maximum despite any solute concentration increase. This situation is unlike that occuring in simple diffusion where an increase in solute concentration is always accompanied by a linear increase in molecular solute flux through the membrane (Giese, 1973). The carrier has been postulated as being either a structure in the membrane or a conformational change in the membrane.

Carrier transport itself may be subdivided into two categories depending upon solute concentrations at equilibrium. If the solute concentrations on each side of the 
membrane are equal at equilibrium, the carrier transport phenomenon is called equalizing transport. If the solute concentrations on each side of the membrane are unequal at equilibrium, the carrier transport is of the concentrative transport type. Equalizing transport is also called facilitated transfer, facilitated diffusion and assisted diffusion, while concentrative transport may be called uphill transport or active transport (Neame et al, 1972).

Differences in the two carrier transport types may also be exemplified by the fact that facilitated diffusion is decreased by a temperature too low to allow metabolism to continue, while active transport is completely stopped at this temperature.

Active transport through a biological membrane can maintain a constant or optimal internal environment within a living system (Iehninger, 1973). This transport, unjike simple diffusion, may occur against an electrochemical potential gradient; electrochemical potential being the total freeenergy change occuring when an ion travels up or down a concentration gradient (Iehninger, 1970). Active transport will transfer a substrate across a membrane unidirectionally only. A good example of active transport is the sodium pump present in many living cells.

Ospina and Hunter (1966) have proposed that facilitated diffusion occurs in mouse and rat erythrocytes. Their findings indicate that the permeability of nouse erythrocytes to thiourea is decreased by butanol. Butanol also decreases 
the permeability of red blood cells of several species of nice to slycerol and the permeability of rat cells to glycerol, ethylene slycol end urea. This lead to the proposal of racilitated diffusion beinf involved in the molecular transfer in mouse and rat erythrocytes.

Uridine transport by mouse blastocysts has been investigated by Daentl and Epstein (1973). Their work has shown that day three nouse blastocysts concentrate uridine radjoactivity to a considerable degree inside the embryo. Uridine permeability is increased dramatically between day one and day tinree of embryonic development and this transport is energy dependent. However, it may not be assumed that this is active transport; facilitated diffusion is also a possibility. Simple diffusion may be excluded as the principal transport mechanism in this case because there is a decrease in tritiated uridine uptake in the presence of non-radioactive uridine. This provides evidence for uridine saturability, a phenomenon present only in the carrier transport mechanism.

Piatigorsky and Whitely (1965) have shown that there is very little perneability to uridine in the unfertilized Strongylocentrotus purpuratus (sea urchin) egg. Data was obtained by measuring the partitioning of tritiated uridine between the insjde and outside of the cell while the egcs remained suspended in the radioactive uridine and after the eggs were washed with sea water. Very little uridine entered the unfertilized esc; after fertilization, however, 
uridine became concentrated in the egg and depleted from the environment. Washing in sea water did not cause a loss of label from the eggs.

Within the first hour of development the rate of uridine uptake leveled off and the eggs concentrated small amounts of exogenous tritiated uridine after the maximal rate of accumulation was reached. Simple diffusion was excluded as the method of transport in this study because saturation was reached when the uridine concentration was raised to a high level and at $-3^{\circ} \mathrm{C}$ only a small amount of uridine entered the eggs. Also, the uptake of uridine was sensitive to 2,4 - dinitrophenol which indicates an energy requirement. For these reasons an active transport mechanism was postulated. Data seems to indicate that the fertilized Strongylocentrotus purpuratus eggs accumulate uridine by phosphorylating the nucleoside at the surface of the cell which is unlike the situation in unfertilized eggs where there is a lack of phosphate donors or of necessary enzymes. Changes in uridine permeability were observed during the maturation of tunicate eggs (Lambert, 1975). Using 5minute pulses of tritiated uridine it was found that, unlike the sea-urchin egg, the unfertilized Ascidia callosa egg is permeable to uridine. However, five minutes after fertilization uptake begins to decline, reaching a low about thirty minutes post-fertilization. An increase in uridine permeability is observed forty-five minutes post-fertilization and levels off approximately three hours post-fertilization. 
Inhibitors, such as p-chloromercuribenzoate, dinitrophenol and thymidine, have little or no effect on the permeability to uridine.

Lambert indicates the possibility of temporary reorganization of the plasma membrane during the fertilizationinitiated completion of meiosis causing the changes in permeability. The possibility of changes in uridine permeability reflecting a change in the extra-embryonic layers has been excluded in this paper since, at hatching, there is only a 25\% decline in uridine uptake. It was stated, therefore, that the embryo itself obtains most of the uridine.

Epel (1972) postulates the activation of an $\mathrm{Na}^{+}$-dependent transport system causing the increase in amino acid permeability upon fertilization of sea urchin eggs.

An increase in the respiratory rate upon fertilization of the eggs of the Ascidian, Phallusia mamillata, was observed by Minganti (1957).

The incorporation of tritiated uridine during the development of the mollusc, Acmaea scutum, was investigated. by Karp (1973) using autoradiographic patterns. The unfertilized eggs incorporate exogenous tritiated uridine as do the fertilized eggs after the fifth cleavage. There is a gradual increase in uridine incorporation in the mollusc from the beginning of the sixth cleavage to the mid-veliger. Karp suggests that there is a general increase in the amount of RNA synthesized per embryo as develonnent proceeds. 
A rise in valine and cytidine uptake after fertilization of sea-urchin egoss was observed by Mitchison and Cummins (1966). An uptake maximum was reached before the first cleavage and remained constant until the fifth interphase. Cell division had no effect on changes in uptake rate. Specific carrier molecules at the cell surface were suggested as the medjators of the transport mechanisms which are activated at fertilization.

Some electrophysical characteristics were studied in the dividing egf of the axolotl, Ambystoma mexicanum (Bozhkova et a], 1974). There is an increase in the total membrane resistance of the eggs before the first division after which follows a rapid decrease during the first division. This resistance remains constant until the thirty-two blastomere stage at which time the membranes of dividing eggs are permeable to $\mathrm{K}^{+}$and $\mathrm{Cl}^{-}$ions.

It has been found that embryos of Paracentrotus lividus utilize exogenously supplied cytidine, uridine, deoxyuridine, thymidine, thymidylic acid and deoxyuridylic acid (Nemer, 1962). The uptake of the $r$ bonucleosides is mainly into acid soluble compounds. It was also found that the amount of uridine uptake increased over developmental time.

Iinear nItryl Benzene Sulfonate

A detergent is composed of several compounds each of which lies in one of the following three categories: surfactant, builder and riscellaneous. The detergent component 
which behaves as a wetting agent and lowers the water surface tension is called a surfactant. The surfactant contains a nonpolar end which is hydrophobic and a polar end which is hydrophilic.

When a substrate is cleansed an adsorption of surfaceactive molecules takes place at the interfaces so that dirt particles are lifted fron the substrate. The surfactant then adsorbs these particles, the hydrophilic end keeping the particles in suspension (Rosen, 1972).

The builder component of a detergent functions as a sequestering agent by tying calcium and magnesium ions into large vater-soluble ions. The water becomes alkaline also via the action of the builder.

Under the miscellaneous category of detergents fall the brighteners, perfunes, anti-redeposition agents and enzynes (Stolker and Seager, 1972).

By 1930 the production of synthetic detergents was quite vast, however, it was not until the 1950's that detergent pollution became recognized as a problem. The anionic detergents have been the most widely studied because of their vast use and their role in detergent pollution (Henderson and Cohn, 1959; Schmid and Mann, 1961).

The builders present little or no problem to the toxicity of the detercent mainly because they are bioderradable. However, the main builders used in detergents contain phosphate and the use of phosphates has caused considerable controversy due to their possible contribution to the eutro- 
phication of natural waters. Detersents represent about 20 to $40 \%$ of the total phosphate released to waters (Jenkins et al, 1973).

A compound that has emerged to replace phosphate in detergent builders is trisodium nitrilotriacetate or INTA. A disappointment, though, lies in the fact that under anaerobic conditions IITA does not degrade and, therefore, may result in its combination with heavy netals such as cadmium or mercury to produce teratogenic effects. Normally, INTA is desraded in the environment and, hence, poses no problem in terms of toxicity to fish (Macek and Sturm, 1973; Stoker and Seager, 1972).

Of the components of detergents, it is the surfactant portion which has caused the greatest concern during the past twenty years. Alkyl benzene sulfonate, ABS, was the most widely used detergent surfactant until the 1960's. By 1962 ABS accounted for 70\% of the surfactant volune of detercents and it was found that the foaming in waterways was caused by the resicues from ABS (Brenner, 1969). Because of its highly branched alkyl structure, this surfactant was found to be very resistant to biodegradation. Consequently, a surfactant displeying a more repidly degradable, straighter alkyl chain came forth as an ABS replacement. This nore modern surfactant is linear alkyl benzene sulfonate, also known as LAS, and it has been considered to be more biologically safe because of its biodegradation properties. This biocegradation has been proposed to occur as a result of the 
oxidation of the terminal methyl group to a carboxylate followed by degradation continuation via beta oxidation. The straighter the alkyl chain, the faster the degradation (Swisher, 1963; Hammerton, 1955). Presently, the most extensively used anionic detergents contain the sodium salis of LAS (Davidson and Milevidsky, 1972).

Inhibition of IAS degradation may occur at certain concentrations due to an interaction between LAS and the bacterial enzymes which would ordinarily degrade the alkyl chain. In this situation IAS is considered to be self limiting. It has been show that IAS degradation was prevented for fifty days at a concentration of 22 ppm LAS at a temperature of $20^{\circ} \mathrm{C}$ (Swisher, 1970).

Abbot (1962) has utilized a technique whereby degradation is analyzed river water at regular intervals following the addition of specific concentrations of surfactants. Studies on surfactant degradation in a sewage lagoon have shown the degradation to be affected by temperature. The lack of molecular oxygen during winter prevented LAS degradation (Halvorson' and Ishaque, 1969). Not all of the degradations of LAS intermediates are known (Swisher, 1967; Swisher et al, 1964).

Surfactants, at high concentrations in water, have a tendency to form aggregations called micelles. The concentration at which this occurs is the critical micelle concentration and it has been shown that only when this is reached is there significant cleansing power (Rosen, 1972). 
Investigations into pollutant toxicity are quite extensive and several methods have been developmed to measure this toxicity to fish (Sprague, 1970).

The first studies on the effects of LAS, when administered orally to mamals, were by Kay et al (1965). They found that IAS caused no adverse effects when fed to rats in concentrations of 200, 1000 and 5000 pom for 90 days.

Dooky (1968) performed an experiment which showed JAS to be less toxic than $A B S$ after 72 hours of exposure in the mosquito minnow (Gambusia affinis).

Nevertheless, numerous experiments have shown LAS to be quite toxic to several species of fish and fish embryos (Cairns and Scheier, 1962; Bardach et al, 1965; Pickering, 1966; Granmo, 1972; Manner and Dewese, 1973; Thatcher and Santner, 1y67).

Willis (1954) has suggested that detergent surfactants may play a role in the inhibition of certain enzymes. Therefore, the failure of some experimental fish to hatch may possibly be attributed to the inhibition of hatching enzymes. The comparative lethal toxicity of a mixture of $A B S$ detergents products to eleven species of fishes was investigated by Thatcher (1966). He found fathead minnows to be more resistant than emerald shiners and bluegills to ABS. Comon shiners, carp and black bullheads were found to be the most resistant. In $A B S$ concentrations approaching $2 \mathrm{ppm}$ the viability of a fathead minnow population becomes threatened. 
In a report by Hokanson and Smith (1971) it was shown that the most important environmental factors influencing the toxicity of IAS to the bIuegill were dissolved oxygen, water hardness, and acclimation to LAS. The most sensitive stage of bluegill development to LAS was the feeding sac-fry while the most tolerant stage was the newly hatched sac-fry. This illustrates the importance of age consideration in detergent toxicity experimentation.

Arthur (1970) subjected three invertebrate species (amphipods) to 96-hour LAS exposures followed by 6-hour exposures of the surfactant. It was determined that the maximum acceptable LAS concentrations were between 0.2 and 0.4 ppm for Gammarus pseudolimnaeus and between 0.4 and 1.0 ppm for Campeloma decisum.

Pickering and Thatcher (1970) have presented data showing the maximur acceptable chronic LAS concentration for fathead minnows to be between 0.63 and $1.2 \mathrm{ppm}$. In this study LAS did not affect hatchability of the minnows, but fry survival was reduced at concentrations of 1.2 and $2.7 \mathrm{ppm}$.

In a review paper by Abel (1974) it was reported that the acute toxic effects of detergents on fish include gill damage, destruction of chemoreceptor organs and epidermis and pharyngeal wall damage. It was also proposed in this paper that detergents probably cause denaturation of proteins and the alteration of membrane permeability and transport characteristics. 
Synergistic reactions have been reported when IAS was administered together with DDM (Dusan, 1967). Solon et al (1969) have found a synergism in the toxic action of a sublethal concentration of IAS and a lethal concentration of the insecticide, parathion, when presented to the fathead minnow. Tests with LAS and the insecticide, endrin, indicated no detectable synergism between these compounds. Synergism jetween IAS and other pesticides which are structurally related to parathion has also been reported (Solon and Nair, 1970).

The Fathead Minnow Chorion

Under normal environmental conditions, the peak spawning of the fathead minnow, Pimeohales promelas Rafinesque, occurs during July. The nales of the species are larger than the females and around the tine of breeding the males become dark in color (Carlson, 1967). The breedinf and early embryology of the fathead minnow have been documented by Manner and Dewese (1974). The water temperature most suitable for breeding was found to be $23^{\circ} \mathrm{C}$. The fertilized egs is approximately $1.0 \mathrm{~mm}$ in diameter and, until hatching, it is surrounded by a clear chorion.

The chorion seems to serve as a protective membrane and the appearance of chorions of several teleost fishes has been reported (Hisaolra, 1958; Zotin, 1958; Kusee, 1949). In all chorions studied "pores" have been reported to occur over the entire, surface. The teleost (zebra fish) chorion, 
although touch and fibrous, has been termed a "leakage neibrane." According to Hisaola (1958), water and electrolytes can readily penetrate through the chorion because of the relatively large diameter of the pores which penetrate through the chorion. Using phase-contrast microscopy, Hisaoka found the pores to be circular in shape, each having an average diameter of $0.0015 \mathrm{~mm}$.

According to Boyd and Simnonds (1974) fertile eggs were made suitable for utilization in embryogenesis studies by Inducing Fundulus heteroclitus minnows to produce eggs lackIng chorionic fibrils.

Chorions protect not only the eges of many species of fish, but also the egss of some insects (Chauvin et al, 1974). The dragonfly egf is surrounded by three membranes, an innermost vitelline membrane and two outer chorionic layers. Each of these memoranes is comoosed primarily of structural proteins (Karasalki et al, 1974).

Mitchison and Swann (1954) compare the unfertilized frog egE to a hollow sphere filled with fluids and surrounded by a solid elastic wall.

Recently, Hagenaier (1974) isolated a chorionic enzyme from the teleost, Salmo gairdneri. This chorionase was isolated specifically from the hatching fluid of the expryo and it is responsible for the initiation of the hatching process itself. 
Yamamoto and Yamasami (1974) studied the morphological changes in the chorion of the teleost, orvzias latioes, caused by the hatching enzyme. It was found that the enzyme digested the inner layers of the chorion, while the oucer layer remained undigested.

The thin outer layer is composed of a sheet of electrondense lamina with a honeycombed outer surface. The inner layer is actually composed of about twelve electron-dense lamellae separated by about eleven interlamellar portions of lover electron-density.

After treatment with the hatching enzyme, the surface of the outer chorionic layer becomes rougher, but remains undigested, while the inner layer undergoes a gradual reduction in the number of Jamellae from innermost side to outermost side until it is completely digested. 


\section{IATERINIS AND IETHODS}

Breeding

Adult fathead minnows were placed in breeding tanks provided with dechlorinated tap water maintained at $23^{\circ} \mathrm{C} \pm 1^{\circ} \mathrm{C}$. The vater vas aerated and conditioned by an in-tank aeration system vith activated charcoal and 3 lass wool filtration. The adult fish were conditioned for breeding by being subjected to a 16-hour daily photoperiod. They were fed daily with brine shrimp, tubifex and a vegetable conditioning food. Inverted halves of 5-inch dianeter clay and asbestos pipes were placed on the botton of the tants. Fertilized eggs were collected from the underside of the pipe-halves. Diffusion and Uotalse

Approximately 250 normal fathead ninnow embryos vere selected at 5, 33, 48, 72 and 96 hours post-fertilization. The embryos, from each of these five age groups, were subjected to a tro-hour treatment of $250 \mathrm{mI}$ of $0.25 \mu \mathrm{Ci} / \mathrm{mI}$ (activity: 29 curies/mol) tritiated uridine. After the twohour treatment, the esss were rewoved and washed three times in aerated, dechlorinated tap vater. This was accomplished by transferring each sroup of embryos into three different petri dishes of weter. These five age groups were then separated into subgroups of ten embryos. The subgroups vere placed in vials containing 15 al of Bray's solution where the embryos were homosenized with a probe. The vials vere placed in a Beckman model scintillation counting chamber 
where radiation counts per minute per embryo were obtained. An additional 250 embryos vere selected at the sane ases of development and were subjected to the same treatment as the controls vith the exception of the addition of a one-hour incubation period in $250 \mathrm{~mJ}$ of a $15 \mathrm{pmm} 11.2$ IAS solution precedine the tritiated uridine incubation. The LAS was $62.4 \%$ active.

If IAS did have an effect on the permeability of the chorion, this should be reflected in an altered scintillation count in the experimental embryos. Comparisons were made, therefore, between the control and experinental enbryos from each group.

As the embryo develops there is a slight increase in its dry weight. The counts per minute per eribryo might not be an accurate measure, for an increase in radioactivity might simply reflect the increased mass of the embryo. To overcome this difficulty, an additional ten enbryos from each of the 5 age groups were placed on filter paper and allowed to dry for 24 hours. These embryos were then weighed and for each age, the average weight of a single embryo was determined. The counts per minute were then calculated as counts per minute per milligrar of embryo. Histolopice? Study

In order to investicate the possibjlity of visible chances, over developmental time, in the morphology of the fathead minno: chorion, another five normal emoryos of each of the following ages: 5, 33, 48, 72 and 96 hours post- 
fertilization, were selected as control embryos.

The chorion surrounding each of these embryos wes removed with forceps, immediately placed on a glass slice and cut into smal]er fragments. One drop of methylene blue (.3\% solution) was placed on the fragments for wetness and staining purposes followed by placement of a coverslip. Slides of each of the 25 chorions vere observed with a compound microscope under oil immersion at X1000 magnification. The circular, pore-like structures observed vere counted with the aid of an optjcal micrometer which was sectioned into squares, each having an area of $1.5625 \times 10^{-4} \mathrm{~mm}^{2}$. Pore-like structures in four squares from five different areas, for a total of 20 squares, in each chorion were counted. Calculations were made to determine the total number of counts per $\mathrm{mm}^{2}$ in each of the 20 squares and a mean of the total number of pore-like structures per mm ${ }^{2}$ in each chorion was determined (Fig. 1). Final results vere recorded as the mean of pore-jike structures per $\mathrm{mm}^{2}$ of chorion at 5, 33, 48, 72 and 96 hours post-fertilization. An additional 25 normal emoryos of 5, 33, 4.8, 72 and 96 hours post-fertilization were selected as INS-treated embryos. They were placed in $25 \mathrm{ml}$ of a $15 \mathrm{pmn} 11.2$ LAS solution for one hour, after which time their chorions were removed and observed in the same nanner explained above for the controls. Final results were recorded as the mean of pore-jike structures per $\mathrm{m}^{2}$ of chorion at $5,33,48,72$ and 96 hours post-fértilization. 
EXPLANATION OF FIGURE 1

Figure 1 Pore-like structures on a fathead minnow chorion observed with an optical micrometer on a compound microscope. 


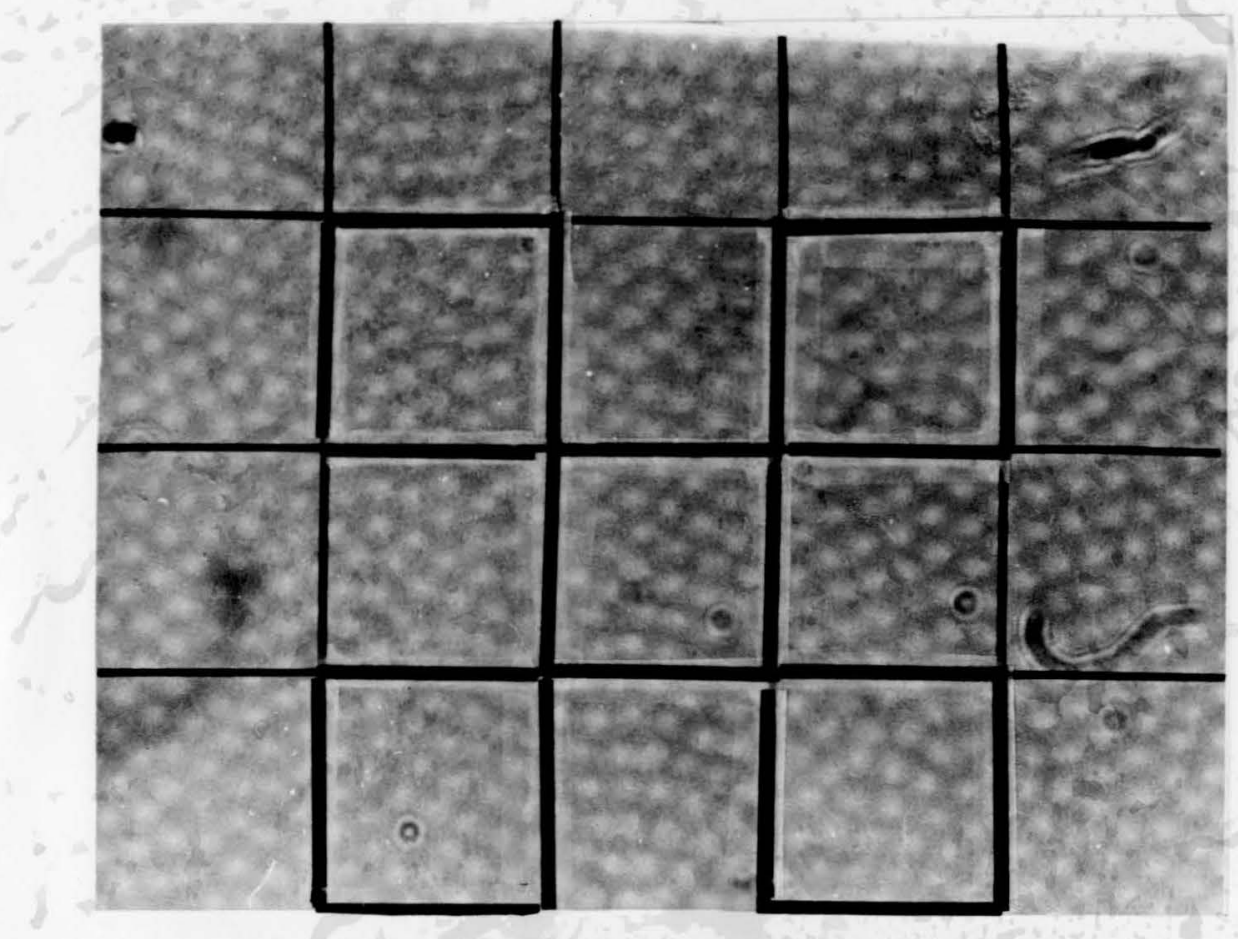

Figure 1 


\section{RESTTTTS}

Diffusion and Untare of Tritjated Uridine

The number of counts per minute per embryo and per milligran of embryo are reported in Table $l$ and graphically presented in Figure 2. An increase in the radiation counts per minute reflects an increased amount of tritjated uridine passing through and renaining within the confines of the chorion.

Effect of InS 으 Diffusion and Untake of Tritiated Uridine The radiation counts per minute per milligram of embryo for the control and IAS treated fathead minnow embryos are reported in Tables $I$ and 2 respectively. Increasing counts per minute represent increasing amounts of tritiated uridine passing through and remaining vithin the confines of the chorion. While these increasing radiation counts are observed. in both control and LAS-treated embryos, the counts for LAStreated embryos are less at all ages studied as comnared to control embryos. These results are also presented graphically in pigure 3.

Histological Study of the Chorion

Pore-like structures were observed on the surface of the chorion at all five developmental aces of fathead minnow embrros studied. These structures can be observed in the photographs in Fieures $4,5,6,7$ and 8 . The mean number 
of pore-like structures per $\mathrm{mm}^{2}$ for each chorion studied along with the mean and standard error of pore-like structures for each of the five age groups of chorions is recorded in Table 3 for the control and in Table 4 for the IAStreated. These results are also presented sraphically in Figure 9. An increase in the number of pore-like structures per $\operatorname{mm}^{2}$ of chorion is observed over developmental time in. both the control and IAS-treated embryos. IAS had no effect on the number of these structures at any of the five developmental ages studied. 
EXPLANATION OF TABIE I

Table I Scintillation counts of embryos subjected to a two-hour pulse of tritiated uridine at five different ages during embryogenesis. 


\begin{tabular}{|c|c|c|c|c|c|c|c|c|}
\hline $\begin{array}{l}\text { Age of } \\
\text { Embryo } \\
\end{array}$ & $\begin{array}{l}\text { No of } \\
\text { Embryos } \\
\text { Tesd }\end{array}$ & $\begin{array}{l}\text { Wej.ght } \\
\text { of } \\
\text { Embryo }\end{array}$ & $\begin{array}{l}\text { Mean of } \\
\text { CPM/ } \\
\text { Embryo }\end{array}$ & $\begin{array}{l}\text { Standard } \\
\text { Deviation }\end{array}$ & $\begin{array}{l}\text { IJog of } \\
\text { Mean of } \\
\text { CPM/ } \\
\text { Embryo }\end{array}$ & $\begin{array}{l}\text { Mean of } \\
\mathrm{CPM} / \mathrm{mg} \\
\text { Embryo }\end{array}$ & $\begin{array}{l}\text { Standard } \\
\text { Deviation }\end{array}$ & $\begin{array}{l}\text { Log of } \\
\text { Mean of } \\
\text { CPM/mg } \\
\text { Embryo }\end{array}$ \\
\hline $5 \mathrm{hrs}$ & 50 & $.22 \mathrm{mg}$ & 88 & 10 & 1.94 & 398 & 46 & 2.60 \\
\hline $33 \mathrm{hrs}$ & 50 & $.29 \mathrm{mg}$ & 520 & 16 & 2.72 & 1792 & 55 & 3.25 \\
\hline $48 \mathrm{hrs}$ & 50 & $.31 \mathrm{mg}$ & 626 & 81 & 2.80 & 2021 & 261 & 3.31 \\
\hline $72 \mathrm{hrs}$ & 48 & $.35 \mathrm{mg}$ & 956 & 56 & 2.98 & 2731 & 160 & 3.44 \\
\hline $96 \mathrm{hrs}$ & 60 & $.39 \mathrm{mg}$ & 1056 & 69 & 3.02 & 2708 & 178 & 3.43 \\
\hline
\end{tabular}

Table 1 
EXPLANATION OF FIGURE 2

Figure 2 tog of counts per minute per embryo

(botton line), and Ior of counts per

minute per milligram of embryo (top line)

plotted againt time of development in

hours. Actual points are indicated.

Each line represents the power curve

fit of these points using the formula:

$y=a x^{b}$. In the case of the counts per

minute per embryo, $a=1.53 ; b=0.15$. In

the counts per minute per milligram of

embryo, $a=2.24 ; b=0.10$. 


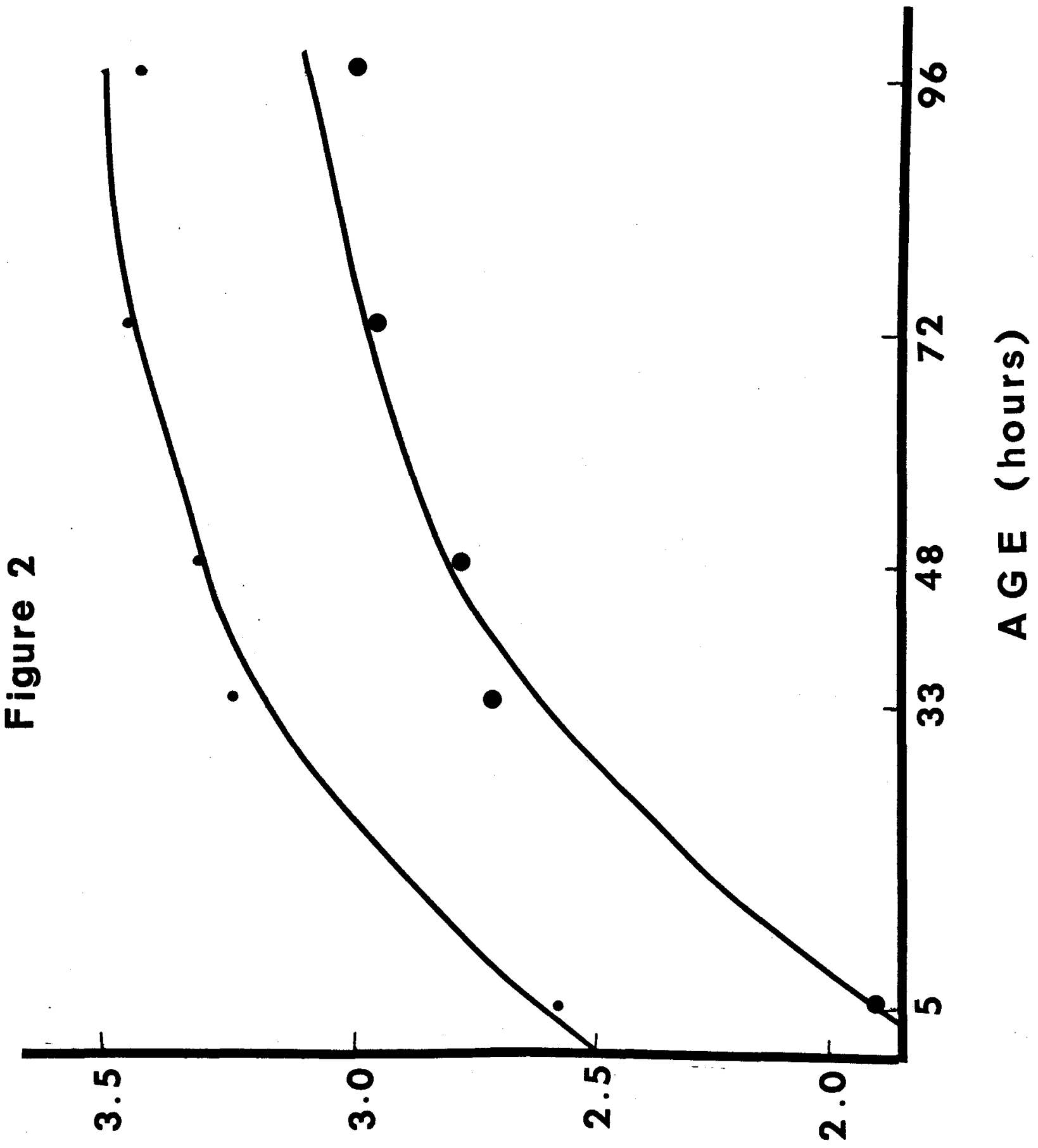

Wd 0 to 907 
EXPLANATION OF TABLE 2

Table 2 Scintillation counts of embryos subjected to a one-hour incubation in $15 \mathrm{ppm} 11.2$ IAS prior to the two-hour pulse of tritiated uridine at five different ages during embryogenesis. 


\begin{tabular}{|c|c|c|c|c|c|c|}
\hline $\begin{array}{l}\text { Are of } \\
\text { Fmbryo } \\
\end{array}$ & $\begin{array}{l}\text { No of } \\
\text { Tribryos } \\
\text { Used } \\
\end{array}$ & $\begin{array}{l}\text { Weight } \\
\text { of } \\
\text { Minbryo }\end{array}$ & $\begin{array}{l}\text { Tean of } \\
\text { CPM/Trmbryo }\end{array}$ & $\begin{array}{l}\text { Standard } \\
\text { Deviation } \\
\end{array}$ & $\begin{array}{l}\text { Mean of } \\
\text { CPM/mg } \\
\text { Embryo } \\
\end{array}$ & $\begin{array}{l}\text { Standard } \\
\text { Deviation }\end{array}$ \\
\hline $5 \mathrm{hrs}$ & 60 & $.22 \mathrm{mg}$ & 39 & 4 & 177 & 17 \\
\hline 33 hrs & 70 & $.29 \mathrm{mg}$ & 321 & 3.1. & 1.705 & 38 \\
\hline $148 \mathrm{hrs}$ & 50 & $.31 \mathrm{~ms}$ & 315 & 77 & 1015 & 248 \\
\hline $72 \mathrm{hrs}$ & 50 & $.35 \mathrm{me}$ & 650 & 27 & 1857 & 78 \\
\hline $96 \mathrm{hrs}$ & 50 & $.39 \mathrm{mg}$ & $85 ?$ & 63 & 2198 & 162 \\
\hline
\end{tabular}

Table 2 
FXPIAATATION OF FIGURE 3

Fisure 3 Comparison between the uptake of tritiated uridine over a four-day period on control. (top Jine) and LAS treated (bottom line) fathead minnow embryos. Actual points are indicated. Fach line represents the power curve of these points using the formula $y=a x^{b}$. In the case of the control, $a=142.56 ; b=.68 ; r^{2}=.98$. In the case of the Ins-treated, $a-46.62 ; b=.85 ; r^{2}=.93$. 
Figure 3

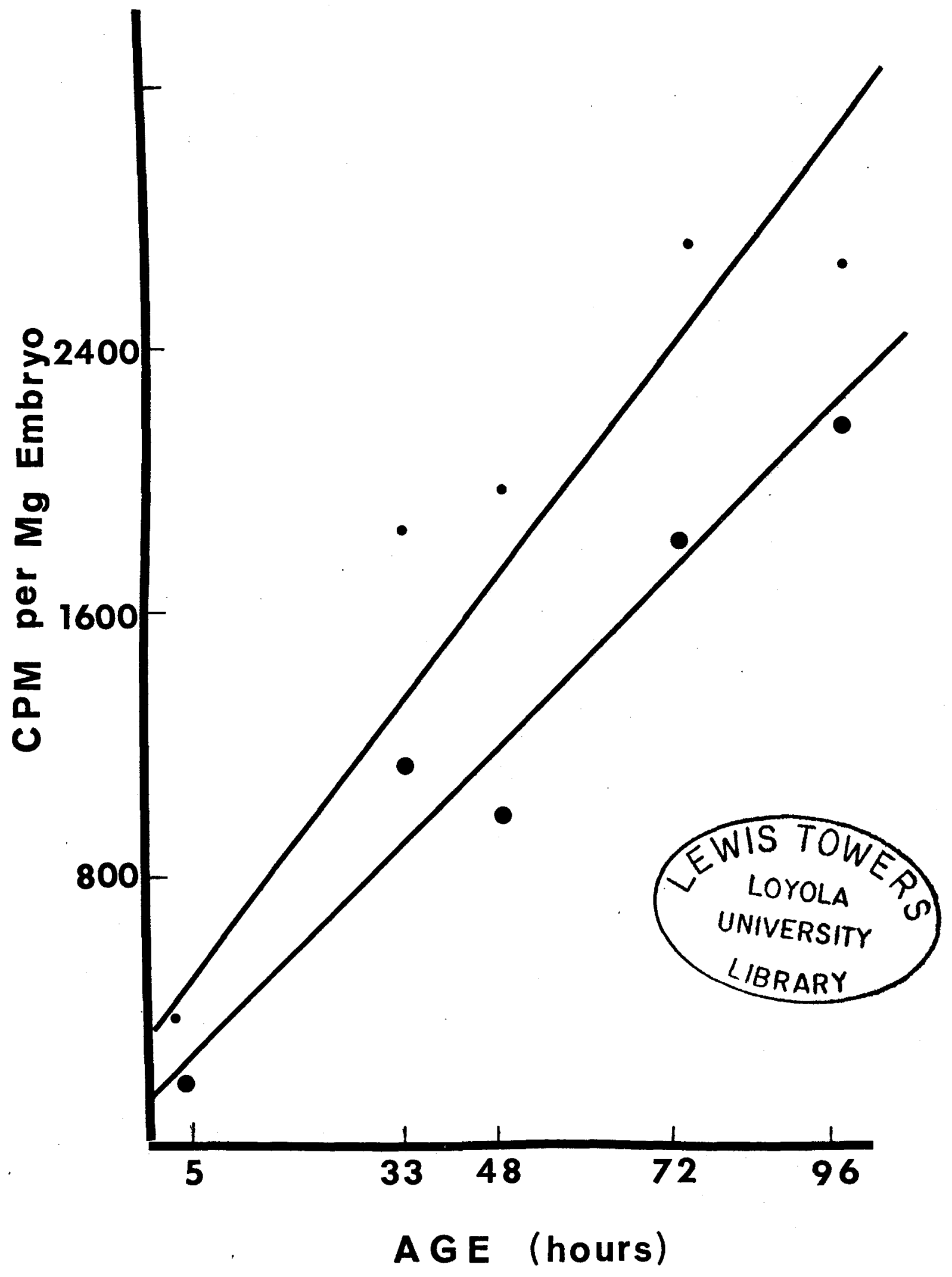


EXPTANATION OF FIGURES 4 AND 5

Figure 4. Chorion of a fathead minnow embryo of 5 hours post-fertilization (XI000).

Figure 5 Chorion of a fathead minnow embryo of 33 hours post-fertilization (X1000). 


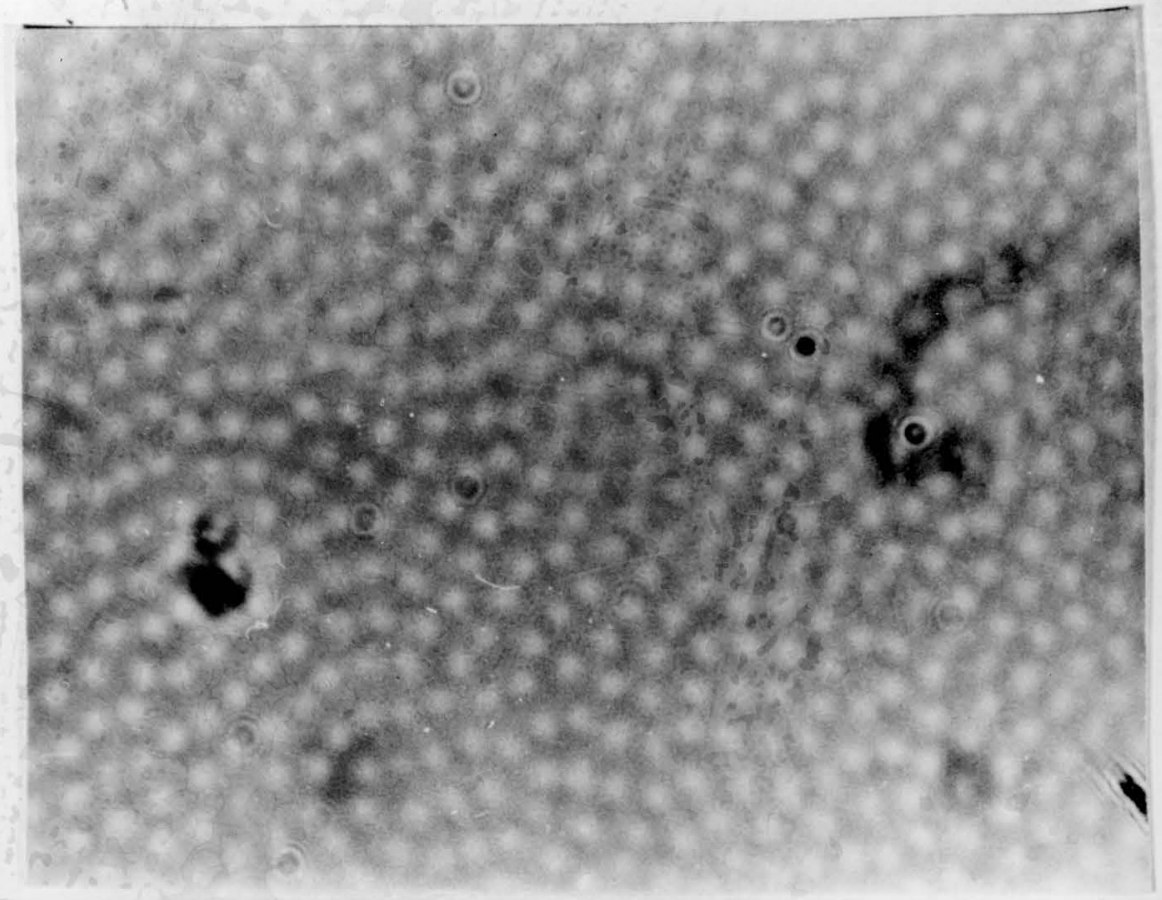

Figure 4

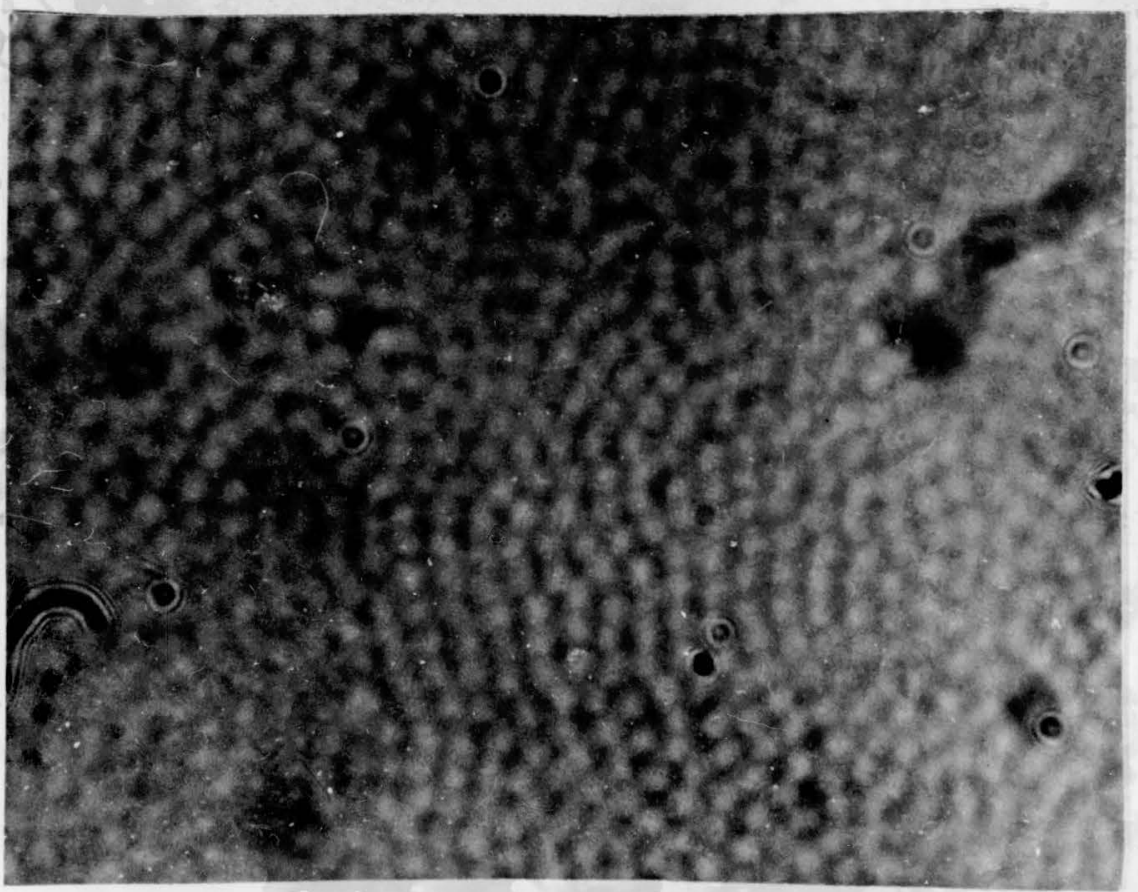

Figure 5 
EXPIANATION OF FIGURES 6 AND 7

Figure 6 Chorion of a fathead minnow embryo of 48 yours post-fertilization (X1000).

Figure 7 Chorion of a fathead minnow embryo of 72 hours post-fertilization (X1000). 


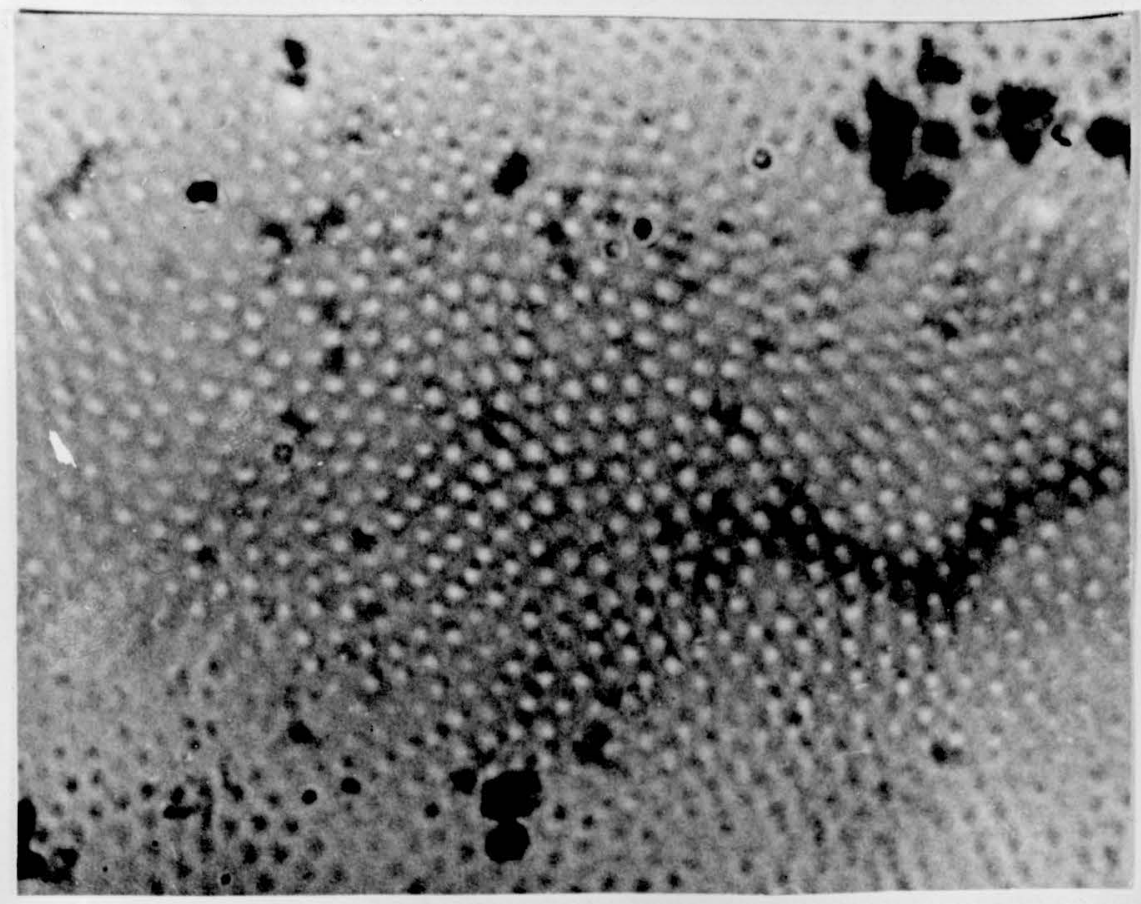

Figure 6

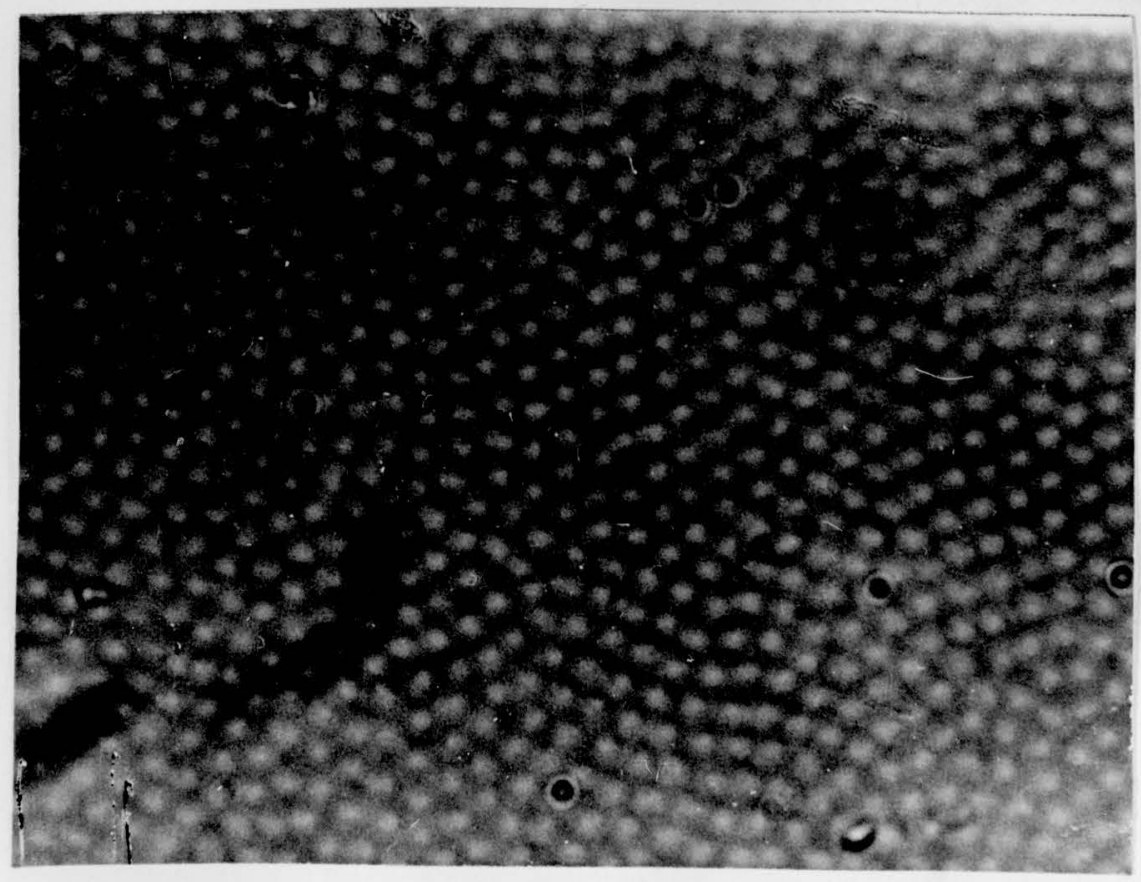

Figure 7 
EXPIANATION OF FIGURE 8

Figure $\gamma$ Chorion of a fathead minnow embryo of 96 hours post-fertilization (X1000). 


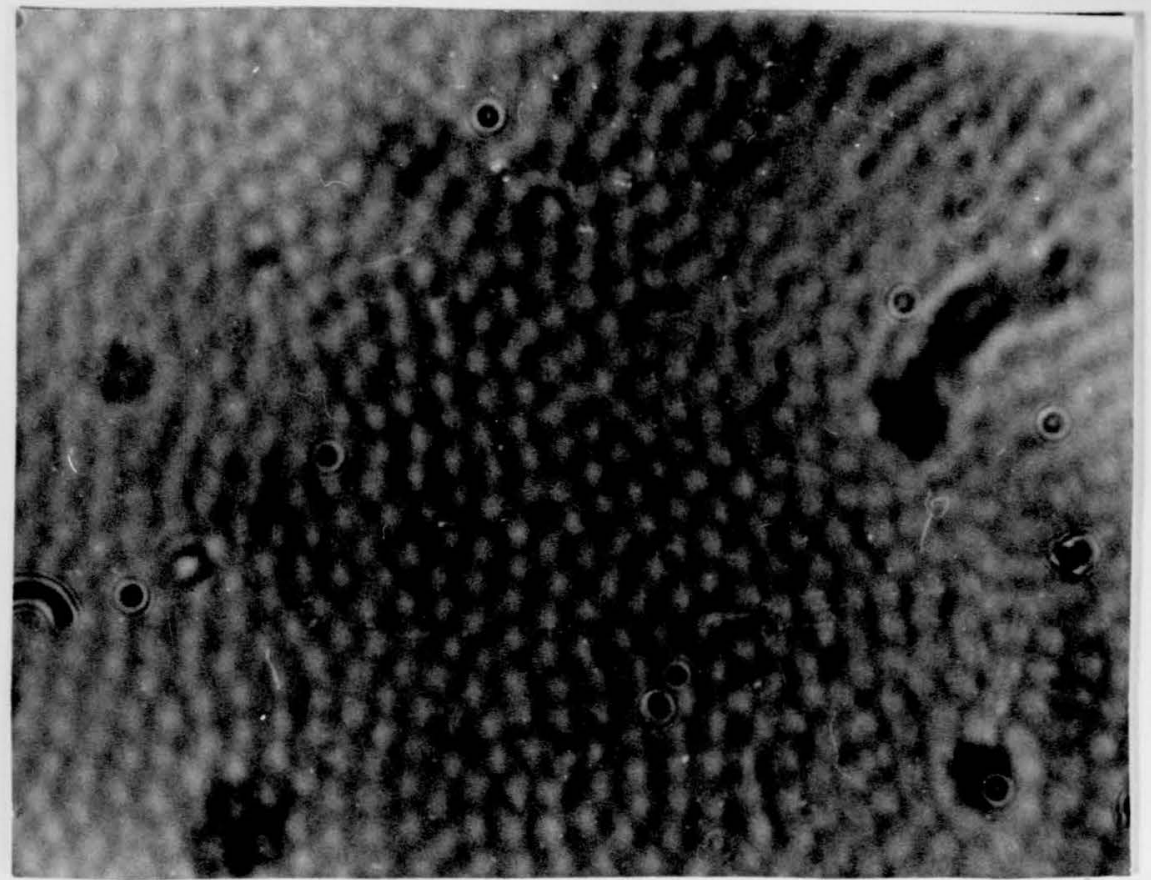

Figure 8 
EXPLANATION OE TABIIE 3

Table 3 Number of pore-like structures observed on chorions of fathead minnow embryos of five different ages during embryogenesis. 


\begin{tabular}{|c|c|c|c|c|c|}
\hline Ace of Embrvo & $5 \mathrm{hrs}$ & $33 \mathrm{hrs}$ & $48 \mathrm{hrs}$ & $72 \mathrm{hrs}$ & $26 \mathrm{hrs}$ \\
\hline $\begin{array}{l}\text { No of } \\
\text { Pore-like } \\
\text { Structures } / \mathrm{mm}^{2}\end{array}$ & $\begin{array}{l}263680 \\
246720 \\
248960 \\
233400 \\
241600\end{array}$ & $\begin{array}{l}227520 \\
259840 \\
236160 \\
255040 \\
265600\end{array}$ & $\begin{array}{l}249280 \\
247360 \\
253440 \\
264960 \\
253440\end{array}$ & $\begin{array}{l}263360 \\
260480 \\
256640 \\
255360 \\
274560\end{array}$ & $\begin{array}{l}288000 \\
266560 \\
261860 \\
275520 \\
270080\end{array}$ \\
\hline Mean No. $/ \mathrm{mrn}^{2}$ & 247872 & 248832 & 253696 & 262080 & 272404 \\
\hline Standard Frror & 3906 & 6498 & 2732 & 3064 & 4018 \\
\hline
\end{tabular}

Table 3 
FIXPLANATION OF TABIE 4

Table 4 Tumber of pore-like structures observed on chorions of fathead minnow embryos after a one-hour incubation in a 15 pom 11.2 IAS solution. Trbryos of five different ages during embryogenesis were used. 


\begin{tabular}{|c|c|c|c|c|c|}
\hline Age of Embryo & 5 hrs & $33 \mathrm{hrs}$ & $48 \mathrm{hrs}$ & $72 \mathrm{hrs}$ & $96 \mathrm{hrs}$ \\
\hline $\begin{array}{l}\text { No of } \\
\text { Pore-like } \\
\text { Structures } / \mathrm{mm}^{2} \\
\end{array}$ & $\begin{array}{l}259200 \\
244760 \\
240960 \\
247360 \\
239630\end{array}$ & $\begin{array}{l}246080 \\
254080 \\
259520 \\
24.920 \\
252480\end{array}$ & $\begin{array}{l}256320 \\
245120 \\
251200 \\
25664_{4} 0 \\
253120\end{array}$ & $\begin{array}{l}261.760 \\
263040 \\
252760 \\
265560 \\
268800\end{array}$ & $\begin{array}{l}256240 \\
272000 \\
274.240 \\
2714240 \\
261440\end{array}$ \\
\hline Mean No. $/ \mathrm{mm}^{2}$ & 246272 & 250816 & 252480 & $2621 \div 64$ & 269632 \\
\hline Standard Frror & $3] .27$ & 2762 & 1879 & 2560 & 2251 \\
\hline
\end{tabular}


FXPTAANATION OF FIGTRR 9

Figure 9 Comparison of the mean number of porelike structures of control (Ist bar) and IAS-treated (2nd bar) fathead minnow chorions of five different ages during embryogenesis. 
Figure 9

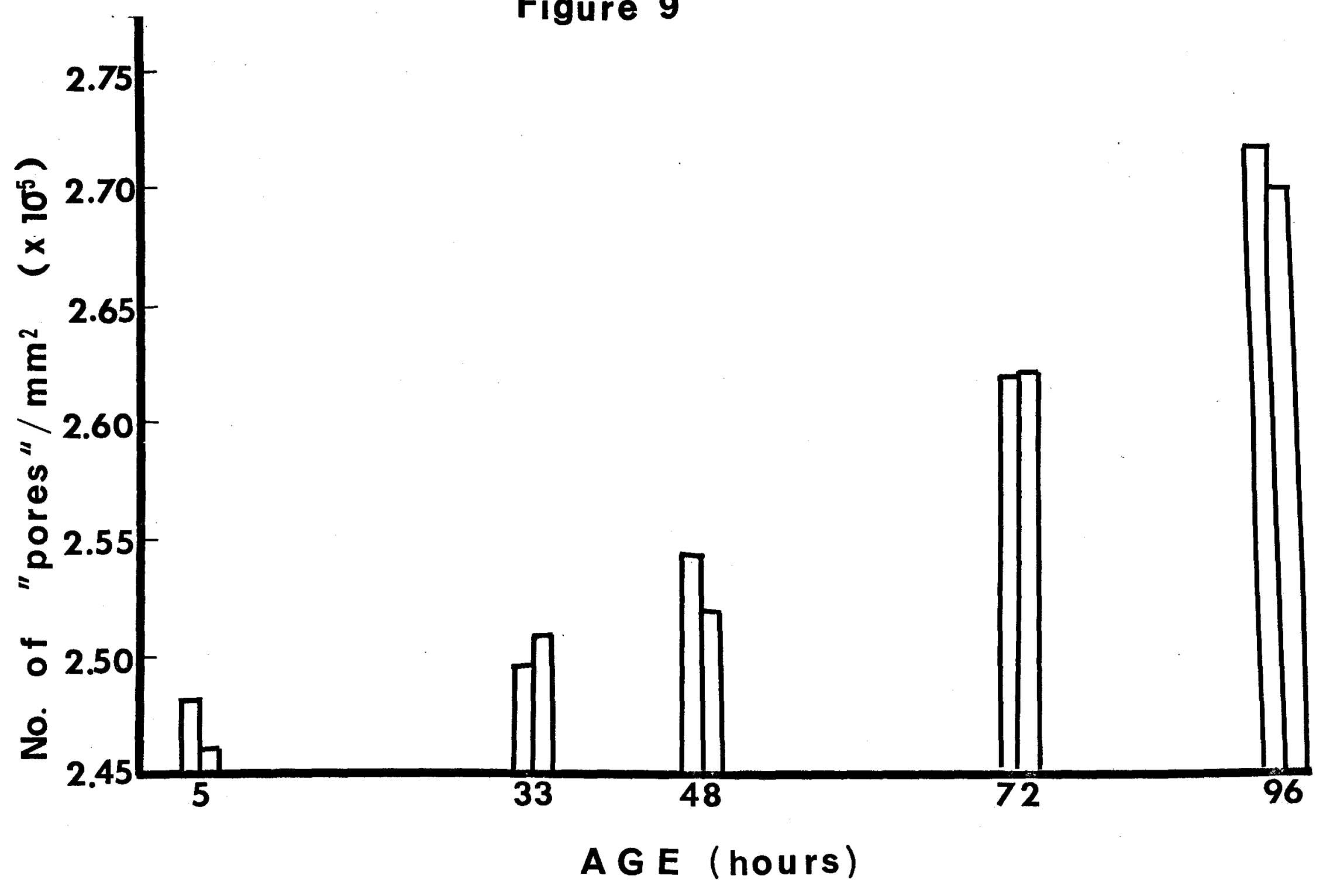




\section{DISCUSSION}

The data presented in this study indicate a change in the diffusion and uptake of tritiated uridine through the vitelline membrane or chorion during the complete period of fathead minnow embryogenesis. Since the chorion is the outermost nembrane surrounding the embryo, particular attention has been paid to the chorion as the barrier between the embryo and its environment.

The increased diffusion and uptake is more pronounced during the first 48 hours of development, but continues to increase along power curve lines throughout the 96 hours of development. To be more accurate, the increased radioactive counts per ninute reflects an increased amount of tritiated uridine which moves through the chorion and is retained there. It should be considered, therefore, as a reflection of the diffusion and uptalse of tritiated uridine by the embryo (Manner and Muehleman, 1975a,b).

Since there may be a slight amount of uridine incorporation in the embryo during the two-hour tritiated uridine pulses, the term "uptake" has also been indicated.

The graphs presented illustrate that the increase in radioactive counts, over developmental time, is not completely linear. There is a slight leveling off of diffusion and uptake as development progresses in the embryo. However, if simpie diffusion alone was involved there mould 
be no increase in radioactive counts per $m_{\delta}$ of embryo since the exogenous tritiated uridine concentration was kept constant. Therefore, I an suggesting the presence of a carrier transport mechanism, along with simple diffusion in this study. The effect of IAS on the diffusion and uptake of tritiated uridine during fathead minnow embryogenesis is one of inhibition. At all developmental ages of the fathead minnow embryo, LAS decreases the amount of tritiated uridine which enters through the surrounding chorion and remains within the embryo.

Since it is possible that a change in chorionic permeability causes the change in diffusion and uptake noted during embryogenesis, it is also possible that the decrease in diffusion and uptake caused by LAS may actually be the action of LAS on the chorion.

Detergent surfactants are capable of adsorbing to cell membranes which may then lead to the depolarization of the cell membrane. In this situation, the net surface charge of the membrane could be changed (Kishimoto and Adel$\operatorname{man}, 1964)$.

It has been noted that there is an increase in the absorption of different materials from the colon of mamals after oral adninistration of surfactants (Iish and Veikel, 1959).

Since surfactants have this effect on membranes, it is conceivable that IAS may change the chorionic menorane, chemically or morphologically, thus, decreasing the rates of diffusion or carrier transport through the membrane. 
If a carrier transport mechanism is involved in the passage of tritiated uricine nolecules through the chorion, the effect of IIAS could possibly be the immobilization of a number of the carrier sites in the nembrane.

From the histological study of the chorion, it was found that the ntimber of pore-like structures on the surface of the chorion increases over developmental time. This increase parallets the increase in diffusion and uptake of tritioted uridine during embryogenesis. Hence, the increase in pore-like structures nay possibly provide an added source of surface area for simple diffusion or additional carrier sites for a carrier transport mechanism. In either or both cases, the amount of tritiated uridine entering and remeining within the confines of the chorion would increase.

From the histological study of the effect of InS on the chorion, it was found that IAS did not change the number of these pore-like structures per $\mathrm{m}^{2}$. The number of structures per $\mathrm{mm}^{2}$ of chorion, both with and wi.thout LAS treatment, were comparable. However, these results do not necessarily mean that IAS has no effect on the chorion. The effect may be purely chemical and therefore not visible in this study; or the effect may be physical, but not visible with the comound microscope. In either case, this stury has proven that ThS does effect the diffusion or carrier transport and uptake of tritiated uridine into the fathend minnow embryo. 


\section{LITERATURE CITED}

Abbot, D.C. 1962. The colorimetric determination of anionic surface-active materials in water. Analyst, 87: $286-293$.

Abel, P.D. 1974. Toxicity of synthetic detergents to fish and aquatic invertebrates. J. Fish. Biol., 6: $279-298$.

Arthur, J.W. 1970. Chronic effects of linear alkylate sulfonate detergent on Gammarus pseudolimnaeus, Campeloma decisum and Physa integra. Water Res., 4: 251-25?.

Bardach, J.E., M. Fujiya and A. Holl. 1965. Detergents: effects on the chemical senses of the Ictalurus natalis (le Sueur). Science, 148: 1605-1607.

Boyd, J.F., and R.C. Simmonds. 1974. Continuous laboratory production of fertile Fundulus heteroclitus (Walbaum) eggs lacking chorionic fibrils. J. Fish Biol., 6: 389-394.

Bozhkove, V.P., I.S. Kvavilashvili and I.M. Chailakhyan. 1974. Some electrophysical characteristics of the axolotI dividing egg. Tsitologiya, 16: 590-596.

Brenner, T.E. 1969. Biodegradable Detercents and Nater Pollution. Technical and Materials Division, The Soap and Detergent Association. N.Y., N.Y. 147-196.

Cairns, J. Jr. and A. Scheier. 1962. The acute and chronic effects of standard IAS upon Pumpkinseed sunfish, Lepomis gibbosus ( $\mathrm{Limn}$ ) and the bluegill sunfish, Lepomis macrochirus, Raf. Proc. I7th Ind. Waste Conf. Purdue Univ., Eng. Exy. Ser., 112: $\frac{14-28 .}{14}$

Carlson, D.R. 196?. Fathead minnow, Pimephales promelas Rafinesque, in the Des Moines River, Boone County, Iowa and the Skunk River drainage, Hamilton and Story Counties, Iowa. Iowa state J. Sci., 4I: 363-374.

Chauvin, G., R. Rahn and R. Barbier. 1974. Comparaison des oeufs des Ievidopteres PhaJera bucepha. I. (Cervridae), Acrolepia assisctella Z. et Plutella maculipennis Curt. (plutellidea): Morphologie et ultrastructures particulieres du chorion au contact du support vesetal. Int. J. Insect Morphol. Embryol., 3: $247-256$. 
DaentI, D.I. and C.J. Epstein. 1973. Uridine transport by mouse blastocysts. Devel. Bio., 31: 316-322.

Davidson, A. and B.M. Milevidsky, 1972. Synthetic Detergents. Billins and Sons Limited, London. pp. 1-37.

Dooky, T.P. 1968. Comparitive effects of ABS and LAS on the mosquito minnow (Gambiensia affines). Texas $\mathrm{J}$. of Sci., 20: 147-155.

Dowben, R.M. 1971. Cell Biolosy. Harper and Row, Ivanston. pp. 409-411.

Dugan, P.R. 1967. Influence of cinronic exposure of anionic detergents on toxicity of pesticides to goldfish. J. Waste Pollut. Cont. Fed., 39: 63-71.

Epel, D. 1972. Activation of an $\mathrm{Ve}^{+}$- dependent amino acid transport system upon fertilization of sea-urchin eggs. Exp. Cell Res., 72: 74-89. Giese, A. 1973. Cell $\frac{\text { Physiology. }}{291 \& 327 .}$. W. Saunders Co.,

Granmo, 1. 1972. Development and growth of eggs and larvae of Mytilus edulis exposed to a linear dodecylbenzene sulphonate, LAS. Harine Bio., 15: 256-358.

Guyton, A.C. 1971. Basic Human Physiology: Normal FuncPhiladeI ohia. D. 33 . Nasease. N.H. Saunders Co.,

Hagenmajer, ㅍ. I. 1974. The hatching process in fish embryos: IV. The enzymological properties of a highly purified enzyme (chorionase) from the hatching fluid of the rainbow trout, salno gairdneri. Comp. Biochen. Physiol., 49: 313- 324 .

HaJ.vorson, H. and $M$. Ishaque. 1969. Microbiology of domestic wastes III. Metabolism of LAS-tyoe detergents by bacteria from a sewage lagoon. Can. J. Microbiol., 15: $572-576$.

Hammerton, C. 1955. Observations on the decay of anionic detersents in natural waters. J.Apol. Chem. (Brit.), 5: $517-524$.

Henderson, C., G.H. and J.M. Cohn. 1959. The toxicity of synthetic detercents and soaps to fish. Sew. and Ind. Wastes., 32: 295-305. 
Hisaoka, K.K. 1958. Microscopic studies of the teleost chorion. Trans. Amer. Microscop. Soc., 77: 240-243.

Hokanson, K. E. and I.I. Smith, Jr. 1971. Some factors influencing toxicity of IAS to the bluegill. Trans. Aner. Fish. Soc., 100: 1-13.

Jenkins, D., W. Kaufman, P.H. McGaubey, A.J. Horne, and J. Gasser. 1973. Dnvironmental impact of detergent builders in California waters. Water Res., ?: $265-281$.

Karp, G.C. 1973. Autoradiographic patterns of tritiated uridine incorporation during the development of the nollusc, Acraea scutum. Exp. Horph., 29: 15-25.

Kawasaki, H., H. Sato and M. Suzuxi. 1974. Structural proteins in the esc envelopes of dragonflies, Sympetrum infuscatum and $\underline{S}$. frequens. Insect Biochem., 4: 99-1I1.

Kay, J.H., F.E. Kohn and J.C. Colandra. 1965. Subacute oral toxicity of a biodegradable, linear alkybenzene sulfonate. Toxicol. Appl. Pharm., 7: 812-818.

Kishimoto, U. and W.J. Adelman, Jr. 1964. Effect of detergent on electrical properties of squid (Loligo pealii) axon membrane. J. Gen. Physio., 41: 975-986.

Kusee, M. 1949. Hardening of the chorion of salmon eges. Cytologia, 15: 131-137.

Lambert, C.C. 1975. Changes of uridine permeability during the maturation of tunicate eggs. Devel. Biol., 46: 40-48.

Lehninger, A.I. 1970. Biochemistry. Worth Publishers, N.Y. pp. 605-626.

Lehninger, A.I. 1973. Bioenergetics. W.A. Benjamin, Inc. pp. $19 i-210$.

Iish, P.M. and J.H. Weikel. 1959. Influence of surfactants on the adsorption from the colon. Toxicol. Appl. Pharm., I: 501-504.

Macek, K. and R. Sturm. 1973. Survival and gill condition of bluegill (Iepomis machrochirus) and fathead minnows exposed to sodium nitrolotriacetate (INA) for 28 days. J. Fish. Res. Bord. Can., 30: 323-325. 
Manner, H.W. and C.M. Dewese. 1973. Biodegradable detergents: a cause of neural anomalies in the developing zebra fish. Trans. Mid. Reg. Dev. Biol. Conf., 1973: $13-14$.

Manner, H.W. and C.H. Dewese. 1974. Early embryology of the fathead minnow, Pimephales promelas Rafinesque. Anat. Rec., 180: 99-110.

Manner, H.W. and C. Muehleman. 1975a. Changes in the permeability of the teleost chorion during embryogenesis. Trans. Mid. Reg. Dev. Biol. Conf., 1975: 21.

Manner, H.W. andzC. Muehleman. 1975b. Permeability and uptake of $\mathrm{H}$-Uridine during teleost embryogenesis. Sci. Biol. Jour., I: 81-82.

Manner, H.W. and D.I. Thompson. 1974. Time of action of IAS on developing zebra fish embryos.

Trans. Mid. Anat. Assoc., 1974: 42.

Minganti, A. 195?. Experiments on the respiration of Phallusia momillsta eges and emoryos (Ascidians). Acta. DHoryoI. Morph. Exp., I: 150-163.

Mitchison, J.M. and M. Swann. 1954. The mechanical properties of the cell surface. II The unfertilized seaurchin egg. J. Exp. Biol., 31: 461-472.

Mitchison, J.M. and J.T. Cumins. 1966. The uptake of valine and sytidine by sea-urchin enbryos and its relation to the cell surface. J. Cell Sci., I: 3547.

Neame, K.D. and T.G. Dichards. 1972. Tlementary Kinetics of Membrane Carrier Transport. Wiley and Sons, Inc.

Nemer, H. 1962. Cheracteristics of the utilization of nucleosides by embrtos of paracentrotus lividus. J. Biol. Chem., 237: 143-T49.

Ospina, B. enc F.R. Funter. 1966. Facilitated diffusion in mouse and rat erythrocytes. Tature, 211: 351 .

Piatigorsky, J. and A.H. Thiteley. 1965. A change in permeability and untake of tritiated uridine in response to fertilization in Stron mlocentrotus purnuretus eces. Biochen. et 3ioprys., 108: 40/4410. 
Pickering, a.H. 1966. Acute toxicity of Alkyl Benzene Sulfonate and Iinear Alkyl Benzene sulfonate to the eggs of the fathead minnow, Pimephales promelas. Air and Water Pollut., 10: 385-391.

Pickering, Q.H. and T. Thatcher. 1970. The chronic toxicity of IAS to Pimephales promelas, Rafinesque. J. WPCF., 42: 243- 254 .

Rosen, M.J. 1972. The relationship of structure to properties in surfactants. J. Aner. Oil Chem. Soc. 49: 293-297.

Schmid, O.J. and H. Mann. 1961. Action of a detergent (dodecylbenzene sulfonate) on the gills of the trout. Nature, 92: 675.

Solon, J.M., J.I. Lincer and J.H. Nair, III. 1969. The effect of sublethal concentrations of LAS in the acute toxicity of various insecticides to the fathead minnow (Pimephales promelas, Rafinesque). Water Res., 3: 767-775.

Solon, J.M. and J.H. INair, III. 1970. The effect of a sub-iethal concentration of LAS on the acute toxicity of various phosphate pesticides to the fathead minnow (Pimeohaies promelas, Rafinesque). Bull. Environment. Contan. Toxicol, 5: 408-413.

Sprague, J.B. 1970. leasurement of pollutant toxicity to fish. II. Utilizing and applying bioassay results. Water Res., 4: 3-32.

Stoker, H.S. and S.I. Seager. 1972. Environmental Cheristry: Air and Water Pollution. Scott, Foresian \&

Swisher, R.D. 1963. The chemistry of surfactant biodegradation. J. Amer. Oil Chem. Soc., 40: 648-656.

Swisher, R.D. 1967. Biodegradation of IAS benzene rings in activated sludge. J. Amer. Oil Chem. Soc., 44: $717-724$.

Swisher, R.D. 1970. Surfactant Biodegradation. Marcel Deklier, Inc.

Swisher, R.D., J.T. ORourke, and H.D. Tomlinson. 1964. Fish bioassays of IAS and intermediate biodegradation products. J. Amer. Oij. wos., 41]: 746-752. 
Thatcher, T.0. 1965. The comparative lethal toxicity of a mixture of hard ABS detergent products to eleven species of fishes. Air and Vat. Pollut. Int. J., 10: $585-590$.

Thatcher, T.O. and V.F. Santiner. 1967. Acute toxicity of IAS to various fish species. Proc. 21 st Purdue Waste Conf., 1966: 996-1002.

Vaughn, J.C. and P.A. Reed. 1973. Progress report of water quality of Ialse Michigan near Chicago. Water and Sev. Works., 73-80.

Willis, E.D. 1954. The effect of anionic detergents and some related compounds on enzymes. Biochem. J., 57: $109-120$.

Yamamoto, $\mathrm{M}$, and $\mathrm{K}$. Yamagami. 1975. Ilectron microscopic studies on choriolysis by the hatching enzyme of the teleost, Orvzias latipes. Devel. Biol., 43: 313321 .

Zotin, A.I. 1958. The mechanism of hardening of the salmonid ess membrane after fertilization or spontaneous activation. J. Embryol. Exp. Morphol., 6: $546-568$. 


\section{APPROVAI SHEPT}

The thesis submitted by Carol Muehleman has been read and approved by the following comittee:

Dr. Harold Nanner, Director

Professor, Biology, Loyola University

Dr. Willian C. Cordes

Assistant Professor, Biology, Ioyola University

Dr. Jan Savitz

Associate Professor, Biolosy, Ioyola University

The final copies have been examined by the director of the thesis and the sionature which apoesrs below verifies the fact that any necessary chenges have been incorporated. and that the thesis is now given final approval by the Comittee with reference to content and form.

The thesis is therefore accepted in partial fulfillmert of the requirements for the degree of Haster of Science in Biology.

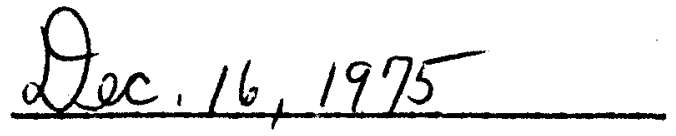

Date

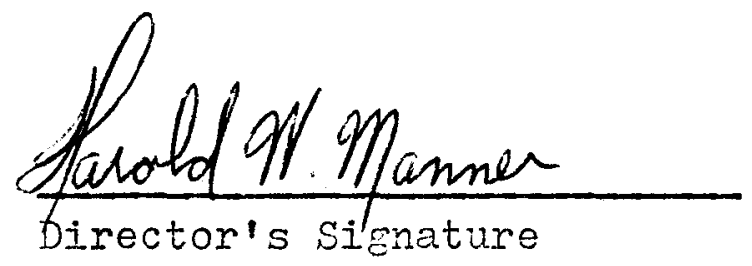

